\title{
С.Ч. Лим*
}

\author{
ИСТОРИЯ САХАЛИНСКИХ АЙНОВ \\ В СВЕТЕ РУССКО-ЯПОНСКОГО СОПЕРНИЧЕСТВА \\ НА ДАЛЬНЕМ ВОСТОКЕ (XVIII в. - сентябрь 1875 г.)
}

\begin{abstract}
Айнский народ, состоявший из хоккайдских, сахалинских и курильских групп, в XIX в. был вовлечен в пограничный спор между Россией и Японией на Дальнем Востоке. Япония насильно переселяла курильских и сахалинских айнов на свою территорию, чтобы в споре с Россией использовать этнический фактор. В итоге курильские айны исчезли как группа в 1940-е гг., а сахалинские остались без родины. Автор анализирует историю сахалинских айнов до их первого насильственного переселения на Хоккайдо в 1875 г.
\end{abstract}

Ключевые слова: сахалинские айны, насильственное переселение, Япония, Россия, исикари-айну, Карафуто, Эдзо

The history of the Sakhalin Ainu and the Russian-Japanese rivalry in the Russian Far East (XVIII century - September, 1875). SOFYA Ch. LIM (Far Eastern Federal University)

In the XIX century the Ainu people, consisting of Hokkaido, Sakhalin and Kuril groups, were involved in the border dispute between Russia and Japan. The latter forcibly resettled the Kuril and Sakhalin Ainu to the Japanese territory in order to use ethnicity in the dispute with Russia. As a result, the Kuril Ainu disappeared as a group in the 1940s and the Sakhalin Ainu were left without their homeland. The article focuses on the history of the Sakhalin Ainu before their first forced relocation to Hokkaido in 1875 .

Keywords: Sakhalin Ainu, forced relocation, Japan, Russia, Ishikari-Ainu, Karafuto, Ezo

До 1868 г. территорией проживания айнов были Эдзо (Хоккайдо), Курильские острова (Тисима или Восточный Эдзо) и южная часть острова Сахалин (Карафуто или Северный Эдзо), сами сахалинские айны называли свою родину энтиу (エンチウ) [38, с. 42]. Известно, что и на севере острова Хонсю сохранились многие признаки пребывания айнов, героически сражавшихся с японцами и постепенно отступавших на север [23, с. 74-78].

В контексте исторических событий XIX и XX вв. существование коренного народа Дальнего
Востока - айнов - полностью зависело от соперничества крупных держав: России и Японии, отчасти и США, и Англии [19, с. 295]. И особенно это соперничество сказалось на судьбе курильских и сахалинских айнов. Проводя разрушительную для традиционной айнской культуры политику японизации, правительство Мэйдзи пыталось установить границу между Россией и Японией на основе «чисто национальной (японской) идентичности», пишет Д. Хаувелл [22, с. 186].

Старшее поколение сахалинских айнов, вынужденных покинуть Южный Сахалин и пере-

* ЛИМ Софья Чунуновна, доктор исторических наук, профессор Департамента истории и археологии Школы гуманитарных наук Дальневосточного федерального университета.

E-mail: lim.sch@dvfu.ru

(C) Лим С.Ч., 2017 
селиться в Японию в 1940-е гг., еще говорило на сахалинском диалекте айнского языка. Но после смерти Асаи Такэ (1902-1994) ${ }^{1}$ на нем никто больше не говорит [35, с. 169]. Политика ассимиляции, проводимая японскими властями по отношению к наиболее многочисленной группе айнов - хоккайдской, также привела к тому, что среди них не осталось тех, кто может вести повседневное общение на родном языке [31, с. 71].

Трагическая история сахалинских айнов связана с историей противостояния России и Японии в вопросе о границах на Дальнем Востоке, в которой выделяются следующие этапы:

1-й этап (1867-1875 гг.) - период русско-японского совместного владения южной частью Сахалина, когда айнское население оказывается заложником противостояния двух держав;

2-й этап (1875-1905 гг.) - остров Сахалин по Санкт-Петербургскому русско-японскому договору полностью становится владением России, уступившей Японии Курильские острова. Этот период наиболее трагичен для сахалинских айнов, часть которых была насильственно переселена японскими властями на Хоккайдо (исикарu-айну, сахалинские мигранты ${ }^{2}$ );

3-й этап (1905-1945 гг.) - поражение России в войне с Японией и переход Южного Сахалина в японские владения создали условия для возвращения на родину почти всем исикари-айну. Тем не менее им, как и всем сахалинским айнам, не удалось избежать постепенной утраты этнической идентичности;

4-й этап (с 1945 г.) - Южный Сахалин и Курильские острова по результатам Второй мировой войны становятся территорией СССР. Уже «японизированные» айны Южного Сахалина заявляют о желании репатриироваться ${ }^{3}$, и в 1948 г., получив разрешение, вслед за японцами покидают свою родину [11, с. 27].

Формат статьи не позволяет раскрыть детали истории сахалинских айнов на вышеуказанных этапах, поэтому здесь мы ограничимся кратким обзором истории XIII-XVIII вв. и периода активного русско-японского соперничества в

\footnotetext{
1 Уроженка северо-западного побережья Сахалина, сказительница айнских сказов - tuytah.

2 Б. Пилсудский называл их «сахалинскими эмигрантами» [5, с. 42].

${ }^{3}$ В СМИ часто используется термин «депортация» айнов, но трагедия истории их репатриации состоит в том, что японцы возвращались на родину, а сахалинские айны покидали землю своих предков. В 1933 г. все они стали подданными Японии [22, с. 187].
}

XIX в. вплоть до сентября 1875 г., когда процесс насильственного переселения части сахалинских аборигенов завершился.

С. Эмори в своей капитальной работе «История айнского народа» разделяет историю подчинения айнов на Сахалине на три основных периода [28, с. 309-315]. В ходе первого периода (XIV в. - 1643 г.) туземные народы Сахалина были данниками Китая. Второй период (с 1635 г. по 1680-е гг.) отмечен продвижением России на Дальний Восток, в том числе на Сахалин, и снижением китайского влияния. Третий период начинается в 1733 г., с распространением влияния японского княжества Мацумаэ на торговлю сахалинских айнов и сантан ${ }^{4}$.

Айны Сахалина издавна вели успешную торговлю на территории Нижнего Амура или с сантан, которые приезжали в Сирануси (Крильон), обменивая меха на стеклянные бусы и «эдзоскую парчу». Р. Мамия в 1809 г., совершая путешествие вдоль западного побережья Сахалина, вышел на побережье Нижнего Амура и в деревне Дерен наблюдал церемонию уплаты туземцами дани цинским чиновникам, а также оживленный торговый обмен [32, с. 77]. Фактически часть сахалинских айнов с начала XIV в. была данниками Китая, которому прежде пришлось с трудом их усмирять в течение почти 40 лет [17, с. 68]. Первое упоминание об айнах (骨嵬 - скорее всего, на нивхском языке; позднее в китайских хрониках слово обозначалось другими иероглифами: 苦兀) встречается в летописях династии Юань в 1264 г. В 1991 г. недалеко от мыса Крильон археологи обнаружили следы земляной крепости, которая, по мнению японских ученых, по типу напоминает военные конструкции династии Юань. Здесь в течение трех лет, примерно с 1284 г., юаньские войска сдерживали айнов. По мнению К. Накамура, конфликт юаньской империи с айнами носил приграничный характер: империи необходимо было защитить своих данников-нивхов от воинственных сахалинских айнов. Последние хотели сами покупать у соседнего народа пушнину, которой нивхи платили дань [32, р. 81-82, 85]. В фольклоре соседних народов, уйльта и нивхов, можно найти свидетельства того, что их отношения с айнами не всегда были мирными [6, с. 41-45].

Р. Симадани считает, что в Японии о Сахалине узнали в 1635 г., а с 1792 г. «сведения о Карафуто появляются в отчетах клана Мацумаэ...

\footnotetext{
${ }^{4}$ Сантан - представители тунгусских народов Нижнего Амура, торговцы.
} 
Причем эти записи были сделаны в то время, когда на острове Карафуто еще не было ни одного русского. ... Что же касается центрального правительства, то оно постоянно оттягивало сроки посылки на Карафуто своих представителей. Только появление вблизи японских владений русских заставило японское правительство в 4 году Кансэй (1792 г.) впервые серьезно отнестись к вопросу изучения Западного Эдзо» $[16$, c. 9$]$.

В 1805-1807 гг. экспедиции И.Ф. Крузенштерна, Н.А. Хвостова и Г.И. Давыдова на юге Сахалина выявили, что 40 японских рыбопромышленников нещадно эксплуатируют 400 айнов, заставляя их летом работать на своих промыслах, а зимой - охотиться и отдавать всю пушнину за долги. Выполняя инструкции Н.П. Резанова, который стремился вытеснить японцев с дальневосточных земель и взять айнов под опеку, лейтенант Хвостов 6 октября 1806 г. прибыл в Аниву, объявил местным айнам, что теперь они подданные Российской империи. Он посетил несколько поселений айнов, которые просили у русских защиты от японцев, роздал им часть продуктов с японских складов [19, c. 43, 92-102].

Относительно небольшое (по сравнению с этим явлением на Хоккайдо) вмешательство японской рыбопромысловой подрядной системы (басё укэой) в жизнь сахалинских айнов пока мало сказалось на их традиционном укладе, особенно в отдаленных селениях северо-западного побережья. Члены французской экспедиции Ж.Ф. Лаперуза при встрече с сахалинскими айнами в июле 1787 г. заметили, что на жизнь последних оказывает влияние маньчжурская торговля [8, с. 20-21]. Европейцы убедились, что туземцы прекрасно разбираются в торговых операциях, прагматичны в выборе товаров и предпочитают железные вещи, ткани, серебро [8, с. 20-21, 24].

Современные западные исследователи полагают, что европейские впечатления об айнах как о добрых и благородных дикарях сформировались именно под влиянием открытий и описаний на рубеже XVIII-XIX вв. Ж.Ф. Ла Перуза на Сахалине, а также В. Броутона и И.Ф. Крузенштерна, находившихся под влиянием идей Pусco [24, c. 22].

В 1791 г. вассалы Мацумаэ на западном побережье Южного Сахалина насчитали 18 айнских селений (всего 86 дворов с 258 туземцами). В основном селения состояли из двух или десяти дворов: в Райситисика было два двора
(18 человек), в Синнаэ - 10 дворов (72 человека). На восточном побережье было 114 дворов (656 человек), были селения и с одним двором. Наиболее крупными поселениями были Томариоро (10 дворов, 63 человека), Сиюя (13 дворов, 77 человек). Таким образом, на юге Сахалина к концу XVIII в. было 200 дворов с 1184 айнами [36, с. 296-297]. «Токунай был первым, кто поставил вопрос о том, что «северные территории» принадлежат Японии» [16, с. 3, 16]. В 1786 г. Могами Токунай после расспросов айнов Эдзо о русских в Карафуто решил, что они там бывали редко и «можно смело утверждать о приоритете японцев на Карафуто». В 1792 г. Могами Т. с отрядом высадился в Сирануси и, продвигаясь к северу по западному побережью Сахалина, понял, что «клан Мацумаэ ведет двойную игру. Ведь его чиновники, посещая эти места, сокрыли следы появления русских, которые являлись такими же нарушителями японских законов, как сантан [16, с. 10-11].

В 1808 г. Мамия Риндзо, старавшийся провести полное обследование юга Сахалина, встречался с айнами, называвшими себя «силун айно». Он насчитал 314 жилищ и 2041 айна на восточном побережье. С учетом данных из других районов общее число населения составляло 2847 жителей. В точности своих подсчетов Мамия Р. сомневался, указывая, что туземцы часто кочуют, проживая то в одной, то в другой семье, даже если они не родственники $[14$, с. 92,106$]$. Система управления в айнских общинах Южного Сахалина была основана на традиционном праве, т.е. главой были вожди (по-айнски - оттена [20, p. 21]), с которыми как японские, так позднее и русские власти старались считаться [37].

Несмотря на заявление Мацумаэ в первой половине XVII в. о том, что дальние земли Эдзо (Карафуто) являются его владениями, постоянной системы управления, возглавляемой японским чиновником, там не было и в XIX в. Во время редких приездов представителей Мацумаэ айнские вожди утверждались в качестве старост и проводили торжественную церемонию выражения вассального подчинения японцам (омуся). В дальнейшем, с появлением японских рыбалок, чиновники начали назначать их сторожами складов и промысловых угодий, а также переводчиками и надсмотрщиками над сородичами $[1$, с. 85$]$, вследствие чего те стали отличаться более высоким имущественным положением и лояльным отношением к японцам.

Активные действия России на Дальнем Востоке в начале XIX в. насторожили сёгунское 
правительство, и в 1813 г. власти Мацумаэ получили распоряжение провести тщательное обследование Сахалина. Кроме того, во избежание безграничного произвола по отношению к айнам на японских рыбалках было решено назначить на местах чиновников для допуска рыбопромышленников только из числа официальных подрядчиков. Жестокая эксплуатация туземного населения не только угрожала его численности, но и расшатывала позицию японского правительства в русско-японских переговорах о Сахалине.

Управляющие хоккайдских басё укэой в 1840-е гг. привезли на Сахалин более ста человек сезонных рабочих-японцев, которые должны были стать сторожами, надсмотрщиками над айнами. На японской рыбалке залива Анива принудительно работали более 1000 айнов, собранных из ближних и дальних селений восточного побережья. Это составляло примерно 2/5 численности всего айнского населения острова. В нерестовые сезоны на промыслах Нотасан (Чехов) на юге западного побережья работали почти все трудоспособные айны. Прежде старейшина Нотэкарима из Сирараоро отказывался заставлять айнов работать на японцев, но постепенно к 1860-м гг. подневольной рабочей силой на предприятиях Анивского залива стали и туземцы северных районов восточного побережья. В 1850-е гг. Мацуура Такэсиро наблюдал, что немало айнских селений почти обезлюдели, оставались только старики и дети. Он описывает жестокую эксплуатацию айнов: мужчин избивали, заставляли работать днем и ночью, женщин-айнок независимо от того, замужние они или нет, принуждали к сожительству с японцами-сторожами. Насильственно оторванных от семейного очага туземных работников селили рядом с промыслом в бараках тако-бэя (タコ部 屋 - комнаты для осьминогов; названы так потому, что в них размещалось большое количество людей). Мацуура Т., с болью наблюдая злоупотребления японцев по отношению к коренному народу, вопрошал, каковы же будут трагические последствия в будущем. Он считал, что корысть, жажда быстрой наживы были главной движущей силой как подрядчиков, так и вассалов самураев княжества Мацумаэ, чувствовавших свою безнаказанность. В конце XVIII и начале XIX вв. в Эдзо приезжали правительственные инспекторы, которые отмечали нищету айнов, работавших в басё укэой, злоупотребления японских смотрителей и их возмутительное отношение к аборигенам. Такая оценка чиновников не была проявлением гуманности, их больше беспокоило то, что такие условия жизни и произвол по отношению к айнам могут настроить их против японцев, когда придут русские [25, c. 53-54]. В Кусункотане (Корсаков) чиновники Мацумаэ проводили церемонию покорности айнов (омуся), одаривая их подарками, собирали сведения о заходах чужих судов, контролировали торговый обмен с сантан в Сирануси. Тем не менее, когда в 1857 г. в Нагасаки прибыла вторая дипломатическая миссия Е.В. Путятина и среди других вопросов обсуждалась спорная проблема Сахалина, выяснилось, что в Японии было мало тех, кто хорошо знал положение дел на острове [25, с. 50, 51, 53].

Россия начала тщательное обследование острова с 1853 г.: с этой целью на Сахалин была направлена экспедиция под командованием Г.И. Невельского. В 1854 г. он установил Муравьевский пост в заливе Анива [12, с. 285], рядом с Кусункотан, который был центром рыбопромышленного и административного управления княжества Мацумаэ [25, с. 73].

В инструкциях 1853 г. майору Н.В. Буссе, остававшемуся временным главой о. Сахалин, Невельской требовал такта и внимательности в отношениях с айнами [12, с. 289]. Лейтенант Н.В. Рудановский провел первичное обследование на юге острова и составил список из 78 селений с числом жителей 2418 человек, а в 1857 г. уточнил, что между широтами 47 и 50 было «всего 95 айнских селений, в них 350 юрт с общим числом жителей 2479 человек» [10, с. 110]. Немногочисленность, а также расселение по небольшим поселениям, разбросанным на некотором расстоянии друг от друга, были свойственны народам, ведущим присваивающее хозяйство с преобладающей ролью рыбалки, охоты и собирательства в суровых климатических условиях Сахалина.

Таблицุа 1

\section{Численность айнского населения Южного Сахалина (1733-1854 гг.)}

\begin{tabular}{|l|c|c|c|c|c|}
\hline Количество: & 1733 г. & 1791 г. & 1808 г. & 1854 г. & 1876 г. \\
\hline- селений (ед.) & - & 25 & - & 78 & 50 \\
\hline- дворов (ед.) & 68 & 200 & 438 & 350 & - \\
\hline- населения (чел.) & - & 1184 & 2847 & 2479 & 960 \\
\hline
\end{tabular}

Источники: [28, с. $313 ; 36$, с. 296-297; 14, с. 92, $106 ; 10$, c. $108-123 ; 15$, с. $6-27]$ 
Ф. Зибольд отмечал, что к концу XVIII в. японцы направили рыбопромысловую и торговую экспансию и на Южный Сахалин, подталкиваемые сведениями об экспедиции Н.П. Резанова и о насильственных действиях Н.А. Хвостова и Г.И. Давыдова против японцев на Курилах и Сахалине [4, с. 251]. О быстрых темпах колонизации японцами Хоккайдо, Курил и Южного Сахалина говорят данные о населении Сахалина (табл. 2): заметна тенденция сокращения численности айнов (до 67,8\%) в период с 1798 г. по 1854 г. и увеличения числа японцев. При этом на севере Южного Сахалина, где влияние японских рыбопромыслов было меньшим, айнское население увеличилось на $125,7 \%$. Численность японцев в Эдзо и южной части Сахалина достигала 63834 чел., но надо учитывать, что это было временное население в период нереста лосося и сельди. В 1854 г. Н.В. Рудановский отмечал, что японские рыбопромышленники в большинстве своем занимались промыслом в сезон нереста и не оставались на Сахалине зимой [9, с. 43-49]. На русско-японских переговорах в 1860-е гг. он указывал на этот факт, а также на то, что японцы занимались рыбалкой в основном в районе залива Анива, а не на простирающейся до 50-й параллели о. Сахалин территории, на которую, как считали японские власти, они имеют историческое право [19, с. 208].

Таблица 2

Численность айнского и японского населения в Эдзо (1798-1854 гг.)

\begin{tabular}{|c|c|c|c|c|}
\hline & 1798 г. & 1807 г. & 1822 г. & 1854 г. \\
\hline Айны & $\sim 20380$ & 26256 & 23563 & 17810 \\
\hline Японцы & 27118 & 31925 & 38686 & 63834 \\
\hline
\end{tabular}

Источник: [28, с. 369]

K концу XVIII в. на японских промыслах аборигенов вынуждали работать до изнеможения, без выходных и за очень низкую плату, лишив их возможности самим обеспечивать свою жизнь традиционными способами: рыбалкой и охотой. Только айнам северо-западного побережья, жившим в отдаленных и малонаселенных селениях, удавалось избегать японского влияния почти до середины XIX в. [1, с. 85].

В ходе русско-японских переговоров в 1855 г. японская сторона пыталась поднять вопрос о Сахалине, в частности - о разграничении сфер вли- яния Японии на юге и на севере острова, что абсолютно противоречило интересам Российской империи. Пока Россия пыталась решить с Японией вопрос о Сахалине, сахалинские айны находились в тягостной неопределенности. Некоторого компромисса требовала и острая необходимость установления торговых отношений России с соседним государством для обеспечения населения дальневосточных окраин необходимыми товарами. Н.В. Буссе отмечал, что ему приходилось всячески лавировать между японцами и айнами, когда последние жаловались на притеснения японских рыбопромышленников и запрет наниматься на работу к русским. Условия не позволяли Буссе и его команде защитить туземцев, что существенно ослабляло позицию русских в глазах туземцев [2, c. $24,43,52,71-72]$. Сами айны, пишет Буссе, не скрывали, что стремятся жить в хороших отношениях и с японцами, и с русскими [3, с. 520].

Японское правительство встревожилось, когда после 1860 г. русские стали усиливать военное присутствие в Кусуннай (Ильинское) и Мануи (Арсентьевка) и продвигаться на юг острова. Правительственные чиновники докладывали, что в Усёро (Орлово) ведется строительство жилья, а среди русских появились и женщины. Здесь же возник и первый русско-японский конфликт, связанный с тем, что русская сторона заступилась за беглого айна Токомбэ. Как сообщал генерал-губернатор Восточной Сибири М.С. Корсаков, японцы всячески препятствовали попыткам айнов наниматься на работу к русским. В январе 1862 г. из басё, управляемого кланом Оно в Усёро, бежал в русское селение, к старшему уряднику Ф. Дьячкову айн Токомбэ, избитый надсмотрщиком. Дьячков отказался выдать его японской стороне. В январе 1863 г. Токомбэ навещал родителей в Усёро и был пойман чиновником Такабаси М. В свою очередь, Дьячков 9 марта явился в Кусунай с 13 вооруженными солдатами и отбил Токомбэ. В течение нескольких дней шли переговоры русских с японцами, в результате чего вышла директива российской стороны о том, что японцы не имеют власти над айнами, а значит те вправе свободно наниматься на работу или к японцам, или к русским [25, с. 164].

Долгие и трудные русско-японские переговоры завершились подписанием 18 марта 1867 г. «Временного соглашения об острове Сахалин» о совместном проживании японцев и русских. В статье 3 отмечалось, что «туземцам на острове предоставляется полная свобода как по личным правам, так и по имуществу. Они могут, по свободному уговору, наниматься к русским и японцам. Если туземец за- 
должает японцу и русскому деньгами или товаром, или состоит уже ныне в долгу, то для уплаты долга может, если пожелает, поступить на услужение на заранее определенное время» $[18$, с. 4,6$]$.

В соглашении ничего не было сказано о конкретных мерах защиты аборигенов от несправедливых условий их эксплуатации на японских промыслах. Японцы заняли все нерестовые реки на юге Сахалина и перекрывали их в устье, не давая лососю подняться выше по реке, несмотря на протест майора Ф.М. Депрерадовича. Тем самым они не оставляли айнам возможности делать рыбные запасы на зиму самостоятельно. Это позволяло японским подрядчикам беспрепятственно порабощать туземное население.

Соглашение 1867 г. позволило русским вновь вернуться в Муравьевский пост, покинутый Н.В. Буссе в 1854 г. в условиях назревавшей войны России с Францией. К концу 1867 г. на Сахалине были выстроены русские посты в Дуэ, Кусунай (Ильинское), Найбучи (Быков), Мануэ (Арсентьевка) и в бухте Буссе, к 1869 г. - пост Корсаков (недалеко от Кусункотан), пост Тихменева (залив Терпения) [19, с. 140, 218, 263-264].

Японское правительство после подписания этого соглашения активизировало «колонизацию Хоккайдо и стало отправлять на Южный Сахалин солдат и преступников. Благодаря поддержке США, Англии и Пруссии оно приступило к разработкам естественных ресурсов Хоккайдо, к строительству казарм и укреплений, готовясь провести эти мероприятия и в южной части Сахалина» [19, с. 294].

Данные о составе пришлого русского населения на Сахалине в 1860-х - 1870-х гг. [38, с. 47-48] свидетельствуют о преобладании государственных служащих (военных и чиновников), а также каторжников, присланных для добычи угля в Дуэ. Таким образом, Россия и Япония по-разному вели колонизационную политику в южной части Сахалина, названной в 1867 г. «территорией совместного проживания». Россия стремилась укрепить дальневосточные рубежи административными методами, усиливая военное присутствие. Это было обусловлено усилением экспансионистских устремлений США, Англии, Франции в странах Дальнего Востока (в первую очередь - в Японии) и угрозой проникновения этих держав на дальневосточные территории России. Японцы же успешнее закреплялись на острове в большей степени посредством экономического освоения, экспансии частного капитала, эксплуатировавшего богатые природные ресурсы и коренное население.

Россия тоже старалась вести экономическое освоение острова - путем развития угольной промышленности, но и здесь применялись административные методы, т.е. использовался труд каторжников. Россия не могла заставлять работать на угольных копях представителей коренных народов. Они работали только по добровольному согласию, если заработок оказывался выше, чем на рыбалке. Но русские испытывали трудности с обеспечением острова рисом, к которому айны уже привыкли, т.к. японцы выдавали его в качестве платы. В этих условиях русские власти предпочитали сохранять лояльность к туземным народам, в то время как экономическая эксплуатация со стороны японских рыбопромышленников приводила к закабалению туземцев, к деградации традиционного образа жизни айнского народа.

Э. Онуки-Тирни подчеркивает, что «по сравнению с остальными айнами Сахалина жители северо-западного берега дружественно относились к русским» [13, с. 24-25], а Н.В. Буссе отмечает независимость, достоинство, здоровый вид северных айнов в отличие от страдающих от золотухи и венерических заболеваний, принесенных японцами, рабски покорных южных сородичей [2, с. 86].

Пытаясь доказать право Японии на остров, японское правительство в 1872 г. приступило к японизации названий айнских поселений Южного Сахалина. Если до этого айнские названия обозначались фонетическим письмом (катакана) (Рис. 1), то теперь для них подбирались иероглифы в соответствии с их звучанием: например, Рутака - ルタカ- 留多加, Оотомари - オオトマ リ- 大泊 и т. д. [28, с. 387]. Японские представители на русско-японских переговорах 1855 г. c Е.В. Путятиным, а также переговорах 1862 г. с Н.П. Игнатьевым пытались утверждать, что сахалинские айны переселились с Хоккайдо, а значит они - «японские подданные», что подтверждает право Японии на Сахалин. Игнатьев потребовал от японцев доказать это написанием названия Карафуто иероглифами, а также объяснить айнские названия на Сахалине и значение слова «айну». Представитель Японии Такэноути признал, что «Карафуто» пишется катаканой, а географические названия Южного Сахалина имеют айнское происхождение [19, с. 168, 207].

Таким образом, к середине XIX в. айнское население на юге Сахалина разделилось на северо-западных айнов, не испытавших какого-либо притеснения русских, и айнов юго-восточного побережья, оказавшихся почти в рабской зависимости от японцев. Ясиро С. отмечал, что на западном побережье было больше айнов от смешанных браков с японцами и с хоккайдскими айнами, а на восточном побережье к северу (р. Поронай) в 


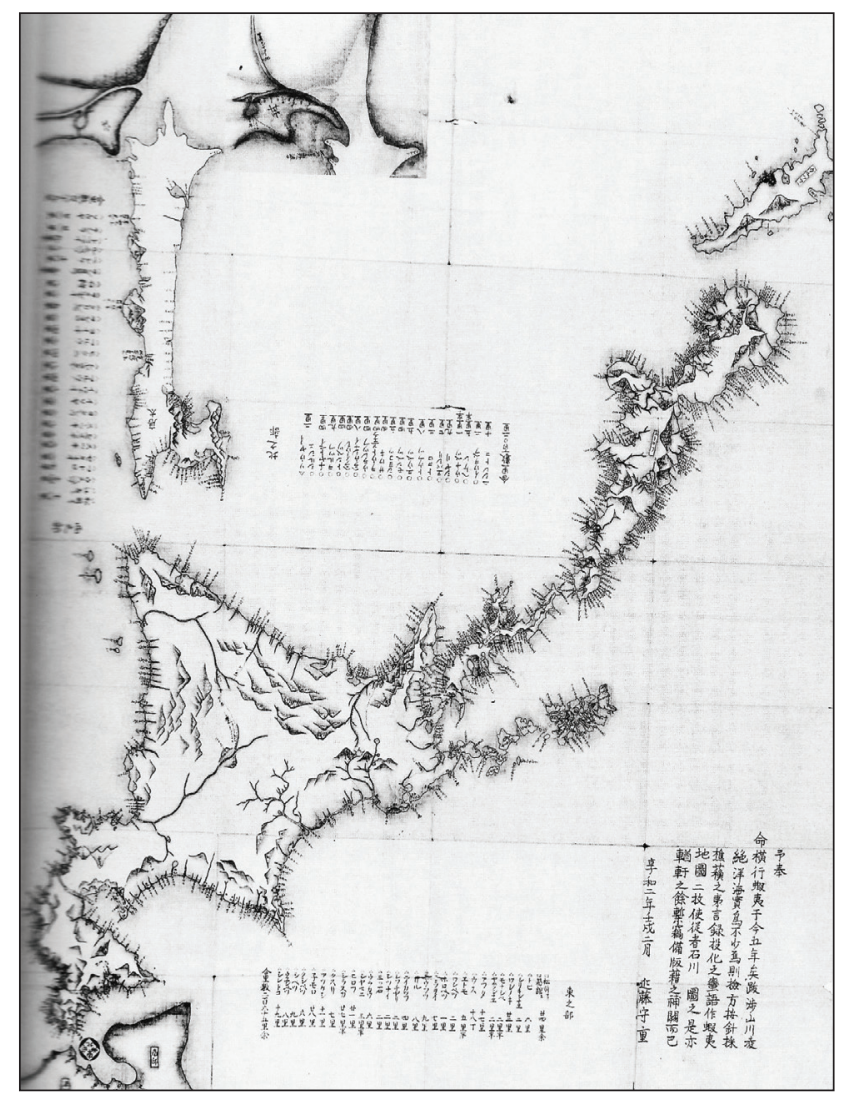

Рuc. 1. Карта территории Эдзо, 1801 г.

Айнские географические названия Южного Сахалина обозначены фонетическим письмом (катакана).

большей степени присутствовала кровь «гиляков и орочон». С другой стороны, в отличие от хоккайдских айнов, среди сахалинских сохранилось больше чистокровных айнов, наследников далеких предков [29, с. 13].

Противостояние России и Японии на Сахалине, при котором страдали больше всего коренные жители, завершилось заключением 25 апреля 1875 г. Санкт-Петербургского договора об обмене Сахалина на Курильские острова. Сахалин перешел в российское владение, но жизнь сахалинских айнов только ухудшилась. После заключения договора 1875 г. и Токийского дополнительного соглашения 22 августа 1875 г. Колониальное бюро Хоккайдо приступило к спешной эвакуации японского населения из Оотомари в Отару - несмотря на то, что по дополнительному Токийскому соглашению переселение японских подданных могло быть осуществлено в течение трех лет. Согласно указанному соглашению, остающиеся после истечения трехлетнего срока жители Сахалина становятся подданными другого государства, т.е. Российской империи [ 25, с. 252-253].

Перед айнами встал трудный выбор: оставаться на своей родине, на Сахалине, и стать подданными России или уехать в Японию. Айнов бес- покоило то, что они оставляют могилы предков, свои дома, привычное окружение и традиции, что им придется жить на чужбине, отрываться от соседей, родных. С другой стороны, с приходом русских их ожидало соседство с каторжниками и надзирателями [38, с. 64-65].

Почему же все-таки айны решились уехать? Японцы с 1809 г. использовали труд айнов на рыбных промыслах Сирануси, Кусункотан и почти за 70 лет организовали рыбные промыслы по всему побережью Южного Сахалина. Так, к 1874 г. на восточном и западном побережьях было 57 рыбалок, 352 построек жилья и складов, 40 синтоистских и буддийских храмов. Айны получали здесь средства для существования, привыкли к рису как к основному продукту питания, то есть стали зависимы от продовольствия, одежды, металлических вещей, получаемых в качестве платы на японских промыслах. Семье из пяти человек на полмесяца едва хватало одного мешка белого риса, и до весны они жили порой впроголодь. Из скудных данных известно, что заработная плата (которая была единственным источником средств существования айнской семьи на год) айнов, работавших на подрядчика Сухара, за промысловый сезон распределялась следующим образом:

- старшины рыбаков, сторожи складов получали 45 мешков неочищенного риса;

- туземные работники получали от 10 до 25 мешков, а также в качестве премии за непрерывную 3-летнюю работу - 1 лаковую посуду, 5-летнюю - 1 меч, 10-летнюю - нарядную накидку [38, с. 65-68].

Таким образом, японцы не только использовали рабский труд айнов, но и, разрушив традиционный образ жизни, привели их к полной зависимости от себя. С другой стороны, японские власти в период совместного проживания русских, японцев и айнов стали понимать роль айнов в пограничном споре с Россией. Они старались умерить аппетиты своих подрядчиков, оказывать помощь больным и престарелым айнам, обеспечивать их рисом и другими продуктами. Во время церемонии омуся чиновники пытались убедить айнов, что русские не являются хозяевами острова [25, с. 179-180].

Под предлогом ликвидации японских рыбалок на Сахалине Колонизационное бюро решило переселить айнов на Хоккайдо. И, как подчеркивает И. Тадзаки, переселение было насильственным, так как японские рыбопромышленники нуждались в даровой рабочей силе на суровом Хоккайдо. Японские чиновники, проведя 17 августа 1875 г. опрос, выяснили, что айны согласны переселиться только в местечко Соя, находившееся напротив 


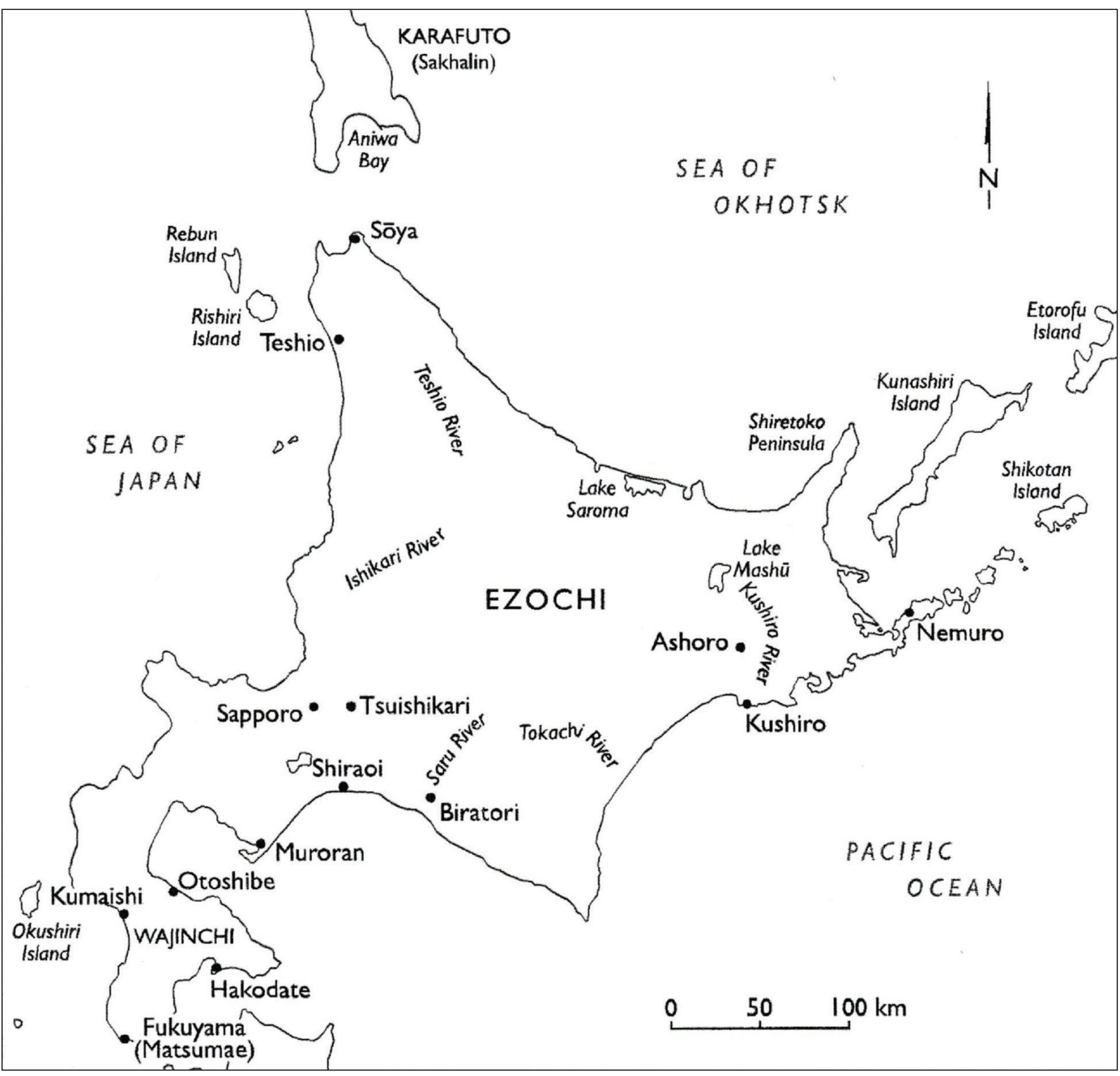

Puc. 2. Карта губернаторства Хоккайдо, 1875 г.

Сирануси [38, с. 49-54, 73], в надежде, что оттуда они смогут навещать могилы предков. Понятие государственной границы им было незнакомо [38, c. 49-54, 73]. Если взглянуть на карту (Рис. 2), видно, что район Соя отделен от родных для айнов мест только нешироким проливом. По природным условиям местечко Соя было похоже на южную часть Сахалина, к тому же одна из двух компаний подрядчика Датэ действовала на Хоккайдо и на Сахалине до 1875 г. [22, с. 188].

Э. Файнберг пишет, что 14 декабря 1875 г. А.Е. Оларовский послал Б.В. Струве возмущенное донесение о том, что японские власти применяли недостойные средства, чтобы убедить айнов переехать в Соя на Хоккайдо. Они угощали и спаивали туземцев, прибегали к помощи несколь- ких влиятельных «объяпонившихся» айнов. И все же большинство айнов осталось на Сахалине: из северных и внутренних районов никто не уехал [19, с. 283-284].

Первое судно с айнами (110 мужчин) было отправлено 9 сентября 1875 г. из Кусункотан в Соя (прошло меньше месяца после Токийского соглашения от 22 августа) [38, с. 78]. Отъезд оказалось спешным и неожиданным для многих айнов, о нем не были оповещены жители дальних от Кусункотан селений, где проживали родственники первых мигрантов. Японские власти в спешке собирали туземцев от Кусункотан по восточному побережью до Сирануси и частично с западного берега - Ниситомиути (район Маока). Почти полностью обезлюдели прибрежные айнские се- 
ления Анивского залива. Только из Оотомари и Кайдзука (Соловьевка) уехало около 300 семей $[29$, с. 13]. Что же им удалось взять с собой? Семья зажиточного айна (9 человек), который находился на службе у японцев, сумела увезти немало ценных вещей: один мешок неочищенного риса, церемониальную лаковую чашу, высокую чашу, ковш, набор лаковых суповых чашек, сосуд для сакэ, 3 подноса с узорами, старинную одежду, ткани, связки табака и другие ценные для них вещи. Другая обычная семья из 5 человек сумела взять только 3 старых домотканых одеяния, 2 куска хлопчатобумажной ткани, 3 курительные трубки, 3 связки табака. Таким образом, отмечает И. Тадзаки, к тому времени под влиянием японцев произошло имущественное расслоение айнов [38, с. 76-79]. Но было немало случаев, когда власти спешно увозили людей без каких-либо вещей, средств к существованию [34, с. 311].

С 9 сентября по 1 октября 1875 г. японские власти организовали три корабля и вывезли через порт Кусункотан 841 сахалинского айна из 108 дворов, которые согласились переселиться в местечко Соя $[25$, c. 63]. К концу сентября 1875 г. была вывезена почти треть сахалинских айнов [34, с. 309]. В итоге этой спешки немало семей было разлучено с родственниками, жившими в дальних селениях на севере Южного Сахалина [25, с. 63].

Подробный анализ настроений айнов конкретных селений с учетом степени влияния на них японцев, выполненный исследователем И. Тадзаки, подтверждает, что переселение айнов не было добровольным. Так, например, айны юго-восточного побережья Карафуто - Кусункотан, Томунайтя, Сакаэхама и др.), а также поселения юго-западного побережья Маока больше всего находились под влиянием японцев, но выехавших в Японию было немного. Например, до 1874 г. в районе Маока было 7 селений с 76 дворами - 551 человек, а выехало не более 98 человек [38, с. 49-54].

Почти сразу после переселения айнов в 1876 г. поручик А.Я. Радковский провел перепись в 50 туземных селениях, в которых оставались около 500 человек мужского пола и около 460 женского, не считая тех, кто проживал в 100 верстах вверх от Кусуная в айнском селении Усёро (26 юрт) численность проживающих там А.Я. Радковскому была неизвестна. Самым крупным селением указывается Маука (Маока), где располагалось 47 юрт со взрослым населением 119 мужчин и 119 женщин, а также детей - 53 мальчика и 45 девочек (всего 336 человек). В отчете о переписи четко указывается, что от Турумая и до самого мыса Крильон айны не живут [15, с. 6-27].
Таким образом, японские власти вывезли только тех, кто жил на самом юге Сахалина, и только треть сахалинских айнов оказалась на севере Хоккайдо. Спешный характер эвакуации части коренного населения и свидетельства самих айнов говорят о насильственном переселении. Скорее всего, отчасти это было вызвано опасением японского правительства, что туземное население юга Сахалина, формально не имевшее подданство Японии, быстро выйдет из-под японского подчинения, что грозило бы утратой в будущем политической основы возвращения на Сахалин. Второй причиной, которую ученые приводят как более существенную, была необходимость сохранить дешевую рабочую силу для эвакуируемых японских промыслов. В этом русско-японском противостоянии наиболее пострадавшей стороной стали сахалинские айны, расселенные по обе стороны пролива Лаперуза. Айнов - сахалинских переселенцев в Соя, которых затем насильственно, с помощью вооруженных солдат, переселили в Исикари, - стали называть исикари-айну, по названию этой местности.

\section{СПИСОК ЛИТЕРАТУРЫ}

1. Акидзуки Т. Японцы и айны на Сахалине (по русским источникам середины XIX века // Краеведческий бюллетень. 1993. № 1. С. 85-100.

2. Буссе Н.В. Остров Сахалин и экспедиция 1852 г. // Вестник Европы. 1871. №№ 10-12.

3. Буссе Н.В. Русские и японцы на Сахалине. Дневник: 10-ое февраля - 11-ое мая 1854 г. // Вестник Европы. 1872. № 10. С. 513-558.

4. Зибольд Ф. Путешествие по Японии или описание Японской империи в физическом, географическом и историческом отношениях. В 3-х т. Т. 2. СПб.: Типография А. Дмитриева, 1854.

5. Из научного архива Б.О. Пилсудского «Некоторые сведения об отдельных айнских стойбищах на о. Сахалине» (не ранее 1907 г.) // Исторические чтения. Труды государственного архива Сахалинской области. № 1. Южно-Сахалинск, 1995. С. 28-46.

6. Икегами Дзиро. Сказания и легенды народа уйльта. Саппоро: Хоккайдский университет, 2007.

7. Ищенко М.И. Формирование русского населения Сахалина (конец XIX - начало XX вв.) // Краеведческий бюллетень. 1993. № 1. С. 45-84.

8. Лаперуз Ж.Ф. Путешествие Лаперуза в Южном и Северном Тихом океане // Краеведческий бюллетень. 1995. № 1. С. 3-50.

9. Латышев В.М. Первые статистические данные об айнах Южного Сахалина // Айны: 
проблемы истории и этнографии. Южно-Сахалинск, 1988. С. 37-50.

10. Латышев В.М. Айнский словарь Н.В. Рудановского // Краеведческий бюллетень. 1991. № 4. С. 108-123.

11. Материалы исследований Б.А. Жеребцова по этнографии айнов Южного Сахалина (1946-1948 гг.). Южно-Сахалинск, 1988.

12. Невельской Г.И. Подвиги русских морских офицеров на крайнем востоке России (1849-1855 г.). М.: ОГИЗ, 1947.

13. Онуки-Тирни Э. Айны северо-западного побережья Южного Сахалина // Краеведческий бюллетень. 1996. № 1. С. 24-25.

14. Описания северного Эдзо, сделанное Мамия Риндзо // Краеведческий бюллетень. 1990. № 2. С. $85-130$.

15. Перепись айнов Южного Сахалина 1876 г., проведенная А.Я. Радковским // Исторические чтения. Труды государственного архива Сахалинской области. № Южно-Сахалинск, 1995. С. 6-27.

16. Симадани Р. Могами Токунай // Краеведческий бюллетень. 2003. № 4. С. 3-19.

17. Стефан Д. Сахалин. История. Перевод с английского Переславцева В. // Краеведческий бюллетень. 1992. №№ 1-4.

18. Трехсвятский А.В. Сахалин в системе русско-японских отношений в XIX столетии // Краеведческий бюллетень. 2004. № 4. С. 3-84.

19. Файнберг Э.Я. Русско-японские отношения в 1697-1875 гг. М.: Издательство восточной литературы, 1960.

20. Batchelor, J., 1926. An Ainu-EnglishJapanese Dictionary. Tokyo: Kyobunkan.

21. Ferloni, J., 2005. Lapérouse: voyage autour du monde. Paris: Grande Bibliothèque Thalassa.

22. Howell, D.L., 2005. Geographies of identity in nineteenth-century Japan. Los Angeles: University of California Press.

23. Kikuchi, Isao, 1999. Early Ainu contacts with the Japanese. In: Fitzhugh, W.W. and Chisato O.D. eds., 1999. Ainu. Spirit of a northern people. Washington, pp. 74-78.

24. Kreiner, J. ed., 1993. European studies on Ainu languages and culture. Munchen: LudiciumVerl.

25. Акидзуки Тосиюки. Нитиро канкэй то Сахаринто. Бакумацу Мейдзи сёнэн рёдо мондай (Японо-русские отношения и остров Сахалин. Территориальный вопрос первых лет эры Мэйдзи). Токио: Тикума сёбо, 1994.

26. Акидзуки Тосиюки. Нихон хокухэн танкэн то тидзу но рэкиси (История исследова- ний и картографии северной части Тихого океана). Саппоро: Хоккайдо дайгаку, 1999.

27. Айну миндзоку ни кансуру сидо сирё (Материалы для изучения айнского народа). Саппоро, 2000.

28. Эмори Сусуму. Айну миндзоку но рэкиси (История айнского народа). Токио: Софукан, 2007.

29. Карафуто Айну но кэнкю: токуни соно дзинко гэнсё мондай ни ситэ (Исследование об айнах Карафуто: проблема резкого сокращения их численности) / ред. Ясиро Сюдзи. Тоёхара, 1927.

30. Китахара Дзирота, Тангику Ицудзи, Тамура Масато. Карафуто айну бунка тёса хококусё (Сообщение об итогах исследования культуры айнов Карафуто). Тиба: Тиба дайгаку, 2000.

31. Мурасаки Кёко. Карафуто айну котоба но судзи ни цуйтэ (О числительных в языке айнов Карафуто) // И Сахарин но гэнго сэкай. Хокудай бунгаку кэнкюка кокай симпозиуму хококусё. Саппоро: Хоккайдо дайгаку, 2009. С. 71-84.

32. Накамура Кадзуюки. Тайрику кара мита тюсэй Ниппон но тиику (Взгляд с материка на северные земли средневековой Японии), Нихон кайики рэкиси тайкэй. 2005. №3. С. 77-102.

33. Нисимура Ивао. Нан Карафуто (Южный Карафуто). Саппоро: Кёгёкумиай Такато инсацу сэнта, 1994.

34. Огава Масахито. Цуисикари гакко но рэкиси. Хоккайдо ни кёсэй идзюсасэрэта Карафуто айну но кёику си (История айнской школы в Цуисикари. Из истории образования сахалинских айнов, насильственно перевезенных на Хоккайдо) / Хоккайдо рицу Айну миндзоку бунка кэнкю сэнта. Кёику гаку кэнкю. 2013. Т. 80. № 3. С. 309-321.

35. Окита Нориаки. Карафуто Айну «Туита» ни мидасарэру коса цуйку (Особенности сказа «Туйта» айнов Карафуто) // Нэнпо дзинруйгаку кэнкю. 2013. № 3. С. 169-191.

36. Такакура Синъитиро. Айну кэнкю (Айнские исследования). Саппоро: Хоккайдо дайгаку сэйкацу кёдокумиай, 1966.

37. Тамура Масато. Ондзонсарэта сютё но якумавари (O сохранении роли деревенских старост) // Хоккайдо. Тохоку кэнкю. 2007. № 4. C. 36-53.

38. Тадзаки Исаму. Цуисикари кёсэй идзю Карафуто Айну кироку (Записи айнов Карафуто о насильственном переселении в Цуисикари) // Ганно исибуми: Карафуто Айну кёсэй идзю но рэкиси. Карафуто Айну си кэнкюкайхэн. Саппоро: Хоккайдо сюппан кикаку сэнта, 1992. C. 39-294. 


\section{REFERENCES}

1. Akidzuki, T., 1993. Yapontsy i ainy na Sakhaline (po russkim istochnikam serediny XIX veka [The Japanese and Ainu on Sakhalin (from the Russian sources of the mid-XIX century)], Kraevedcheskiy byulleten', no. 1, pp. 85-100. (in Russ.)

2. Busse, N.V., 1871. Ostrov Sakhalin i ekspeditsiya 1852 [Sakhalin Island and the expedition of 1852], Vestnik Evropy, no. 10-12. (in Russ.)

3. Busse, N.V., 1872. Russkiye i yapontsy na Sakhaline. Dnevnik: 10-oe fevralya - 11-oe maya 1854 g. [The Russians and Japanese on Sakhalin], Vestnik Evropy, no. 10, pp. 513-558. (in Russ.)

4. Zibol'd, F., 1854. Puteshestvie po Yaponii ili opisaniye yaponskoy imperii v fizicheskom, geograficheskom i istoricheskom otnosheniyakh. $\mathrm{V}$ 3-kh tt. [Journey through Japan or description of the Japanese Empire in physical, geographical and historical relations. In 3 volumes]. SanktPeterbugr: Tipografiya A. Dmitrieva. (in Russ.)

5. Iz nauchnogo arkhiva B.O. Pilsudskogo «Nekotorye svedeniya ob otdel'nykh ainskikh stoybishchakh na o. Sakhaline» (ne ranee 1907 g.) [From the archives of B.O. Pilsudski "Notes about individual Ainu nomad camps on Sakhalin" (not earlier than 1907)]. In: Istoricheskiye chteniya. Trudy gosudarstvennogo arkhiva Sakhalinskoy oblasti, no. 1. Yuzhno-Sakhalinsk, 1995, pp. 2846. (in Russ.)

6. Ikegami, D., 2007. Skazaniya i legendy naroda uyl'ta [Tales and legends of the Uilta people]. Sapporo: Hokkaidskii universitet. (in Russ.)

7. Ishchenko, M.I., 1993. Formirovaniye russkogo naseleniya Sakhalina (konets XIX nachalo XX vV.) [Formation of the Russian population of Sakhalin (late $\mathrm{XIX}^{\text {th }}-$ early $\mathrm{XX}^{\text {th }}$ century)], Kraevedcheskiy byulleten', no. 1, pp. 45-84. (in Russ.)

8. Laperuz, J.F., 1995. Puteshestviye Laperuza v Yuzhnom i Severnom Tikhom okeane [The voyage of La Perouse in South and North Pacific], Kraevedcheskiy byulleten', no. 1, pp. 3-50. (in Russ.)

9. Latyshev, V.M., 1988. Pervye staticheskiye dannyye ob ainakh Yuzhnogo Sakhalina. [The first statistical data on the Ainu of Southern Sakhalin]. In: Ainy: problemy istorii i etnografii. YuzhnoSakhalinsk, pp. 37-50. (in Russ.)

10. Latyshev, V.M., 1991. Ainskiy slovar' N.V. Rudanovskogo [Ainu dictionary of N.V. Rudanovsky], Kraevedcheskiy byulleten', no. 4, pp. 108-123. (in Russ.)
11. Materialy issledovaniya B.A. Zherebtsova po etnografii ainov Yuzhnogo Sakhalina (1946-1948) [Materials of the research by B.A Zherebtsov on the ethnography of the Ainu of Southern Sakhalin, 1946-1948]. Yuzhno-Sakhalinsk, 1988. (in Russ.)

12. Nevel'skoy, G.I., 1947. Podvigi russkikh morskikh ofitserov na kraynem vostoke Rossii (1849-1855) [The feats of Russian naval officers in the Russian Far East, 1849-1855]. Moskva: OGIZ. (in Russ.)

13. Onuki-Tirni, E., 1966. Ainy severo-zapadnogo poberezh'ya Yuzhnogo Sakhalina. [Ainu of the northwest coast of South Sakhalin], Kraevedcheskiy byulleten', no. 1, pp. 24-25. (in Russ.)

14. Opisaniya Severnogo Edzo, sdelannoye Mamiya Rindzo [Description of the north Ezo made by Mamiya Rinzō], Kraevedcheskiy byulleten', 1990, no. 2, pp. 85-130. (in Russ.)

15. Perepis' aynov Yuzhnogo Sakhalina $1876 \mathrm{~g}$. provedennaya A.Ya. Radkovskim [The 1876 census of Ainu people of Southern Sakhalin carried out by A.Ya. Radkovskiy], Istoricheskiye chteniya. Trudy gosudarstvennogo arkhiva Sakhalinskoy oblasti, no. 1. Yuzhno-Sakhalinsk, 1995, pp. 6-27. (in Russ.)

16. Simadani, R., 2003. Mogami Tokunay [Mogami Tokunai], Kraevedcheskiy byulleten', no. 4, pp. 3-19. (in Russ.)

17. Stefan, D., 1992. Sakhalin. Istoriya. [Sakhalin. The history], Kraevedcheskiy byulleten', no. 1-4. (in Russ.)

18. Trekhsvyatskiy, A.V., 2004. Sakhalin V sisteme russko-yaponskikh otnosheniy $\mathrm{V}$ XIX stoletii [Sakhalin in the system of Russian-Japanese relations in the $\mathrm{XIX}^{\text {th }}$ century], Kraevedcheskiy byulleten', no. 4, pp. 3-84. (in Russ.)

19. Fainberg, E., 1960. Russko-yaponskiye otnosheniya v 1697-1875 gg. [Russian-Japanese relations, 1697-1875]. Moskva: Izdatel'stvo vostochnoy literatury. (in Russ.)

20. Batchelor, J., 1926. An Ainu-EnglishJapanese Dictionary. Tokyo: Kyobunkan.

21. Ferloni, J., 2005. Lapérouse: voyage autour du monde. Paris: Grande Bibliothèque Thalassa.

22. Howell, D.L., 2005. Geographies of identity in nineteenth-century Japan. Los Angeles: University of California Press.

23. Kikuchi, Isao, 1999. Early Ainu contacts with the Japanese. In: Fitzhugh, W.W. and Chisato O.D. eds., 1999. Ainu. Spirit of a northern people. Washington, pp. 74-78.

24. Kreiner, J. ed., 1993. European studies on Ainu languages and culture. Munchen: LudiciumVer1. 
25. 秋月俊幸, 1994 . 日露関係とサハリン 島. 幕末明治初年の領土問題 [Japanese-Russian relations and the Sakhalin Island. Territorial issue of the end of Tokugawa era and the first years of Meiji era]. 東京: 筑摩書房. (in Japanese)

26. 秋月俊幸, 1999. 日本北辺探検と地図の歴 史 [A history of the exploration and cartography of the North Pacific]. 札幌: 北海道大学図書刊行会. (in Japanese)

27. アイヌ民族に関する指導資料 [Materials for the study of the Ainu people]. 札幌, 2000. (in Japanese)

28. 榎森進, 2007. アイヌ民族の歴史 [History of the Ainu people]. 東京: 草風館. (in Japanese)

29. 屋代周二 ed., 1927. 樺太アイヌの研究: 特にその人口減少問題に就いて [The study of the Sakhalin Ainu: with focus on the population decline problem]. 豊原. (in Japanese)

30. 北原次郎太、丹菊逸治、田村雅人, 2000. 樺太アイヌ文化調査報告書 [A report on the study of Sakhalin Ainu culture]. 千葉県: 千葉大 学. (in Japanese)

31. 村崎恭子, 2009. 樺太アイヌ語の数詞につ いて [Numerals in the Sakhalin dialect of Ainu]. In: サハリンの言語世界: 北大文学研究科公開 シンポジウム報告書. 札幌: 北海道 大学, pp. 7184. (in Japanese)

32. 中村和之，2005. 大陸から見た中世日本 の北方地域 [Northern areas of medieval Japan as seen from the continent], 日本海域歴史大系, Vol. 3, pp. 77-102. (in Japanese)

33. 西村いわお, 1994. 南樺太 [South Karafuto]. 札幌: 協業組合 高遠印刷センター. (in Japanese) 34. 小川正人, 2013. 対雁学校の歴史. 北海道 に強制移住させられた樺太アイヌの教育史 [A history of Tsuishikari School: educating Sakhalin Ainu children forcibly relocated to Hokkaido], 北 海道立アイヌ民族文化研究センター「教育学

研究」, Vol. 80, no. 3, pp. 309-321. (in Japanese)

35. 大喜多紀明，2013。樺太アイヌの「トゥ イタ八」に見出される交差対句 [The features of “Tuytah” tales of Karafuto Ainu], 年報人類学研 究, no. 3, pp. 169-191. (in Japanese)

36. 高倉新一郎, 1966. アイヌ研究 [The studies on Ainu]. 札幌: 北海道大学生活協同組 合. (in Japanese)

37. 田村将人，2007. 温存された酋長の役 割. 樺太庁が任命した樺太アイヌの「土人部落 総代」について [Preserving the role of village chiefs. On "the chiefs of aboriginal villages" of the Sakhalin Ainu, appointed by the local government of Krafuto], 北海道· 東北史研究 第, no. 4, pp. 36-53. (in Japanese)

38. 田崎勇, 1992. 対雁強制移住樺太アイヌの記 録 [The records of the Sakhalin Ainu about the forced migration to Tsuisikari]. In: 雁の碑: 樺太アイヌ強制 移住の歴史. 樺太アイヌ史研究会 編. 札幌 : 北海 道出版企画センター, pp. 39-294. (in Japanese)

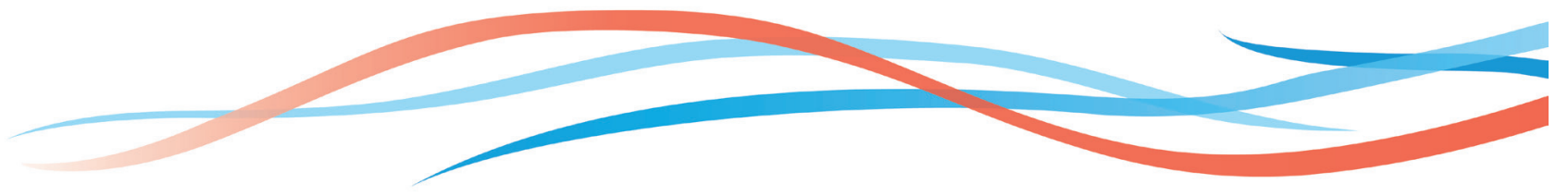

